\title{
Erratum To: Ukrainian Migration to the European Union
}

\section{Lessons from Migration Studies}

\section{Olena Fedyuk and Marta Kindler}

(C) The Editor(s) (if applicable) and The Author(s) 2016. This book is published open access.

O. Fedyuk, M. Kindler (eds.), Ukrainian Migration to the European Union,

IMISCOE Research Series, DOI 10.1007/978-3-319-41776-9

\section{DOI 10.1007/978-3-319-41776-9_14}

This book was mistakenly published under a CC BY 4.0 license, but has now been made available under a CC BY-NC 2.5 license. The PDF and HTML versions of the book have been updated accordingly. 